Natuschka M. Lee (Ed.)

Biotechnological Applications of Extremophilic Microorganisms

Life in Extreme Environments 


\section{Life in Extreme Environments}

Series Editor

Dirk Wagner

Volume 6 


\section{Biotechnological Applications of Extremophilic Microorganisms}

Edited by

Natuschka Lee

DE GRUYTER 
Editor

Natuschka M. Lee

Department of Ecology and Environmental

Science

Umeå University

Linneaus väg 6

90187 Umeå, Sweden

natuschka.lee@umu.se
Series Editor

Dirk Wagner

GFZ German Research Centre for Geosciences, Helmholtz Centre Potsdam

Section Geomicrobiology

Telegrafenberg

14473 Potsdam, Germany

dirk.wagner@gfz-potsdam.de

ISBN 978-3-11-042773-8

e-ISBN (PDF) 978-3-11-042433-1

e-ISBN (EPUB) 978-3-11-042436-2

ISSN 2197-9227

Library of Congress Control Number: 2020939096

Bibliographic information published by the Deutsche Nationalbibliothek The Deutsche Nationalbibliothek lists this publication in the Deutsche Nationalbibliografie; detailed bibliographic data are available in the Internet at http://dnb.dnb.de.

(c) 2020 Walter de Gruyter GmbH, Berlin/Boston Cover image: robertcicchetti/iStock/Getty Images Typesetting: Compuscript Ltd., Shannon, Ireland Printing and binding: $\mathrm{CPI}$ books $\mathrm{GmbH}$, Leck

www.degruyter.com 